\title{
PUBLIC PARTICIPATION IN TIMES OF PRIVATISATION: A HUMAN RIGHTS ANALYSIS
}

\author{
Jeroen Temperman*
}

\begin{abstract}
Privatisation may not only affect the enjoyment of the right to public participation itself, but might also impact other substantive rights. This article charts some of the ramifications of privatisation in relation to individual human rights as enshrined in international human rights conventions, with a particular focus on the impact privatisation has on the right to public participation. The right to public participation can be seen as both an example of a fundamental right that may be affected by processes of privatisation and, at the same time, potentially being the key to remedying (part of) the adverse impact privatisation has on the enjoyment of other fundamental rights.
\end{abstract}

Keywords: public participation, privatisation, human rights, informed consent in decisionmaking processes

\section{Introduction}

The traditional protection mechanism that underlies and motivates international human rights law is rather straightforward. The state is identified as the principal duty bearer, whilst the individual is the primary rights holder, and thus the main beneficiary of this body of law. Put another way, in the international legal order it is typically only the state (i.e. not private actors) that can be directly held accountable for a violation of applicable international human rights standards. Thus, the foundational principles of international human rights law regarding the addressees of this body of law unveil inherent shortcomings - some of which were arguably hard to anticipate when the international human rights framework was first developed at the end of the Second World War. A number of these inherent shortcomings can be pinpointed as follows:

- First, international human rights law has only limited potential to hold non-state actors (e.g. transnational corporations, companies, organisations, individuals) directly accountable for violations of human rights law.

- Second, the optimal impact of international human rights law could become subverted if the state were to lose control over what traditionally were considered public affairs (e.g. through processes of privatisation or globalisation), since under international law no alternative (private) party is necessarily designated by default as principal or derived duty bearer.

This article will deal with the second shortcoming described above. The issue of privatisation can meaningfully be distinguished from the problématique surrounding non-state actors. The issue of the (non-)accountability of non-state actors in principle pertains to all adverse effects of acts or omissions not attributable to the state, including not only acts of private companies but also, for instance, acts of NGOs, international organizations, or private persons. It is clear that not all instances of wrongful acts attributable to non-state actors are linked to processes of privatisation. In recent years, (quasi-) legal initiatives, studies, and legal doctrine dealing with the issue of the accountability of non-state actors have mushroomed. ${ }^{1}$ These initiatives range from soft

\footnotetext{
Assistant Professor of Public International Law, Erasmus University Rotterdam; Erasmus Fellow; and Editor-in-Chief of Religion \& Human Rights: An International Journal.

For some of the work in these fields, see e.g.: P. Alston (ed.), Non-State Actors and Human Rights (2005); A. Clapham, Human Rights Obligations of Non-State Actors (2006); CSR studies include: ILO, Governance, International Law \& Corporate Social Responsibility (ILO/ International Institute for Labour Studies Research series no. 116, 2008); on self-regulation, see for instance: A. Kolk \& R. van Tulder,
} 
law benchmarking, self-regulation, discourses on corporate social responsibility (CSR), to actual legal strategies to prevent impunity in the area of wrongful acts committed by non-state actors. Different stakeholders, with the overall view towards improving the effectiveness and impact of international human rights law, have looked into various legal methods for holding non-state actors directly or indirectly accountable. Such proposals have, for instance, involved attempts to hold non-state actors accountable for breaching national law within the domestic legal order (e.g. tort law). This strategy may occasionally remedy a concrete situation of impunity under international law, but will ultimately not contribute to direct accountability of non-state actors for acting contrary to international human rights law. Alternatively, responsibility for adverse practice by non-state actors is occasionally realized through the (derivative) responsibility of states. That is to say, wrongful acts committed by non-state actors may under circumstances be attributed to states (e.g. if states remained in control of the situation); or states may occasionally be considered to be responsible by omission, that is, for failing to comply with applicable due diligence obligations (i.e. the state should have controlled the situation better). These strategies, too, may prove successful in concrete instances, but either way we are back to the responsibility of states for wrongful acts, something not necessarily conducive to holding non-state actors directly accountable for international wrongful acts.

Having said that, it will be clear at the same time that the issue of privatisation may in specific instances be more or less inextricably linked with the problems surrounding the (non-)accountability of non-state actors. Privatisation might, after all, turn former state(-controlled) organs into private actors.

Turning to examine the main focus of this account - the privatisation of public affairs - this contribution will address the impact of this phenomenon in the context of human rights law. Stated in general terms, the issue is as follows: states make widely varying commitments by virtue of signing up to international human rights treaties. These include pledges to uphold basic civil liberties of the individual, commitments concerning equal treatment of all persons, guarantees in the field of political rights, as well as economic, social and cultural rights, such as the right to work and adequate working conditions, the right to social security, the right to an adequate standard of living including adequate food, water, clothing and housing, and the right of access to health care as well as education. The process of privatisation creates a situation whereby the actor who is considered to be the primary duty bearer under international law - the state - is not de facto responsible for the goods or services at hand. That is to say, although legally speaking the state can still be identified as having primary responsibility under international human rights law, its official commitments are belied by the (low) level of control it exercises in the relevant areas.

As a consequence, privatisation affects the enjoyment of the right to public participation itself, but might also impact on other substantive rights. In section 2 , the international standards on public participation will be outlined. Paradoxically, when participatory rights are most expressly spelled out in the relevant convention (i.e. ICCPR), the related treaty-monitoring body (i.e. Human Rights Committee) shows reluctance to construe that norm beyond traditional suffrage rights. It is the other core UN human rights treaties and benchmarks formulated by related treaty-monitoring bodies that have either pro-actively mainstreamed participatory rights with other substantive human rights guarantees, or that insist on more direct rights of informed consent. Although this trend did not necessarily result from privatisation, it could be argued that these broader participatory norms may nevertheless serve a purpose in the light of this challenge. The impact of privatisation on other substantive rights will also be elaborated upon. In section 3, it will be argued that the UN Committee on Economic, Social and Cultural Rights presently appears to be the most progressive body in terms

'The Effectiveness of Self-regulation: Corporate Codes of Conduct and Child Labour', 20 European Management Journal 3, at 260-271. In 2000, the UN launched the UN Global Compact, an initiative to encourage private business enterprises to align themselves with international human rights standards (among other things, such as combating corruption). For the UN Global Compact principles, its mandate and initiatives, consult: $<$ http://www.unglobalcompact.org/>. 
of mainstreaming the right to public participation with substantive (socio-economic) rights. Section 4 considers the limits of what can be attained by way of participatory rights with reference to the privatisation of education.

\section{The Right to Public Participation}

Let us begin by scrutinizing the general standards concerning the right to public participation in light of the challenges posed by privatisation. Under international human rights law, every citizen has the right and the opportunity to take part in the conduct of public affairs. Privatisation problematises the state's obligations in the following ways. Due to privatisation, the scope of what constitutes public affairs diminishes, meaning that in the absence of corresponding safeguards, or a necessary contemporary discourse on rethinking participatory rights, the legal potential of the right to public participation might diminish accordingly. Under international law, it is far from self-evident that wherever the state steps down from its formal role as principal provider, a private duty bearer steps in by default. This private provider may be subject to domestic regulations, but will hardly ever be considered to be truly, directly subject to international standards. Typically, this private entity will not even qualify as an international legal subject proper. Naturally, this does not mean that international human rights law ceases to apply altogether once the state steps down from its role as provider of certain - traditionally considered public - goods or services. On the contrary, it is the state that signed up to the original obligation to ensure various individual entitlements, and it remains the state that may be held accountable for failing to live up to that original commitment.

These considerations do not, as such, rule out the possibility for the state to step down as the principal provider in any of the relevant former public areas, be it regarding civic or socio-economic entitlements. However, these considerations do suggest that in such instances it all the more pressing for the state to have guarantees in place ensuring that (former) public goods and services are properly and equally accessible, or - as the case may be - allocated in an equitable fashion. The state may ultimately be legally responsible for any failure. This would generally be the case if and when it is possible to prove that inequitable access or allocation by private providers is (despite privatisation) nonetheless attributable to the state. This would occur if the state continues to exercise a degree of control over the service or good at stake. Despite the absence of a clear attribution of inequitable - or otherwise wrongful - conduct to the state, it may still be possible to prove that the state did not comply with applicable due diligence obligations and thus is ultimately responsible as a consequence. A due diligence obligation, in the present context, could be described as a positive obligation upon the state going beyond the mere avoidance of acting in breach of fundamental rights, and extending to all necessary efforts aimed at actively preventing third parties from infringing upon fundamental rights.

Applying this to the right to public participation, the following may be considered. First of all, under international law, it is the state that must ensure that every citizen enjoys the right and the opportunity to take part in the conduct of public affairs. This does not imply that privatisation within the realm of public affairs is entirely out of the question. However, the existence of the international norms concerning participatory rights, and the importance attached to them, would imply that eminent positive obligations are incumbent upon the state to ensure that privatisation of the public realm goes hand in hand with introducing guarantees for continued respect for the population's participatory rights.

Before it can be assessed how far these positive obligations extend in the context of privatisation, one needs to understand the meaning and scope of the right to public participation. Depending on how widely or narrowly the actual right to public participation is interpreted, one can make assessments as to the (potential) impact of privatisation on this right, as well as to the continued meaning, scope and pertinence of this right in times of privatisation in light of apparent positive obligations. 


\subsection{The Meaning and Scope of the Right to Public Participation: The Traditional Nexus with Political Power}

It is first necessary to outline the meaning and scope of the right to public participation as originally laid down by the drafters of the International Bill of Rights, and to make an inventory of what state obligations precisely emanate from this norm. The mother of all contemporary formulations of participatory rights provided for a rather narrow framing. Article 21 Universal Declaration of Human Rights (1948) provides:

(1) Everyone has the right to take part in the government of his country, directly or through freely chosen representatives.

(2) Everyone has the right of equal access to public service in his country.

(3) The will of the people shall be the basis of the authority of government; this will shall be expressed in periodic and genuine elections which shall be by universal and equal suffrage and shall be held by secret vote or by equivalent free voting procedures. ${ }^{2}$

Participatory rights, as set out in the UDHR, are largely limited to suffrage and the right to run for public office, and are guaranteed in relation to participation in the government. The right 'to take part in the government of one's country', and the corresponding suffrage rights, are arguably narrower than 'a right and the opportunity to take part in the conduct of public affairs', as enshrined in the International Covenant on Civil and Political Rights (1966). ${ }^{3}$ The ICCPR provides in article 25:

Every citizen shall have the right and the opportunity, without any of the distinctions [such as race, colour, sex, language, religion, political or other opinion, national or social origin, property, birth or other status] and without unreasonable restrictions:

(a) To take part in the conduct of public affairs, directly or through freely chosen representatives;

(b) To vote and to be elected at genuine periodic elections which shall be by universal and equal suffrage and shall be held by secret ballot, guaranteeing the free expression of the will of the electors;

(c) To have access, on general terms of equality, to public service in his country.

According to Nowak, the change from government to public affairs did not so much occur as a result of the desire to broaden the scope of participatory rights, but rather is indicative of the drafters being 'intentionally vague in order to allow States parties to structure the right to democratic participation in a manner consistent with the various models of democracy'. ${ }^{4}$ Whereas the UDHR is strictly speaking a non-binding Resolution adopted by the UN General Assembly (although it is largely considered to represent customary international law), the ICCPR binds the 167 states that are party to it. ${ }^{5}$ However, a number of states have expressed reservations (partly or altogether) to the legal ramifications of article $25 .^{6}$

Turning to the question concerning the precise meaning and scope of participatory rights contained in this covenant, it is useful to commence with the beneficiary of this right. In this respect the ICCPR provision on public participation is, in actual fact, narrower than the UDHR equivalent: Article 25 ICCPR purports not to protect the rights

\footnotetext{
Universal Declaration of Human Rights, G.A. res. 217A (III), U.N. Doc. A/810 at 71 (1948), 10 December 1948 [hereinafter the UDHR].

International Covenant on Civil and Political Rights, G.A. Res. 2200A (XXI), 21 U.N. GAOR Supp. (No. 16) at 52, U.N. Doc. A/6316 (1966), 999 U.N.T.S. 171, 16 December 1966 (entered into force: 23 March 1976) [hereinafter the ICCPR].

M. Nowak, U.N. Covenant on Civil and Political Rights: CCPR Commentary (2005), at 570.

State of play at the time of writing (February 2011).

Including: Kuwait (reservation to article 25(b)); Monaco; Pakistan; Switzerland; and the UK (reservation to Article 25(b) and (c)). Both Finland and Sweden have objected to the reservations of Kuwait. Both Chile (in 1976) and Georgia (in 2007) have derogated from Article 25 as a result of a state of emergency (something that is permitted as long as such derogations are in accordance with Article 4 ICCPR).
} 
of everyone but of citizens only. In recognition of the difference between article 25 and the other Convention rights, the Human Rights Committee is adamant that states should report their national legal provisions defining citizenship. ${ }^{7}$ Moreover, the Committee also stated that:

No distinctions are permitted between citizens in the enjoyment of these rights on the grounds of race, colour, sex, language, religion, political or other opinion, national or social origin, property, birth or other status. Distinctions between those who are entitled to citizenship by birth and those who acquire it by naturalisation may raise questions of compatibility with article 25 . State reports should indicate whether any groups, such as permanent residents, enjoy these rights on a limited basis, for example, by having the right to vote in local elections or to hold particular public service positions. ${ }^{8}$

Regarding the content and scope of the right, article 25 expressly provides that citizens shall have the right and the opportunity to take part directly in the conduct of public affairs, or indirectly through freely chosen representatives.

Exercising one's voting rights in relation to (representative) public affairs bodies (i.e. the gist of indirect participation), cannot readily remedy the adverse effects of privatisation, as it is the process of privatisation that precisely prejudices what constitutes public affairs. Hence, the present account is mostly concerned with possible modalities to give effect to direct participation, such as consultation schemes, referendums/ plebiscites/ballot questions, taking part in popular assemblies, or other forms of directly involving stakeholders in decision-making processes. This is in addition to actively running for public office and potentially exercising power as a member of a legislative body or by holding executive office, which also falls under direct participation.

Some brief consideration of indirect participation (exercising voting rights) would also appear to be appropriate as a preamble, if only to contextualize and appreciate its counterpart. Although the Committee formally adheres to the subsidiarity principle and holds that indirect participation can be realized in a multitude of different constitutional systems, ${ }^{9}$ the Committee has repeatedly hinted that a democracy is the only system of political organization compatible with the Covenant. ${ }^{10}$ The suffrage rights enshrined in paragraph (b) of Article 25 further conceptualise the right to take part in public affairs indirectly. ${ }^{11}$ A significant part of the workings of the Human Rights Committee on this article (in terms of its relevant General Comment, Concluding Observations on state reports, and Views in relation to individual communications) aim at conceptualising this

General Comment 25: The right to participate in public affairs, voting rights and the right of equal access to public service (Art. 25), (Fifty-seventh session, 1996), U.N. Doc. CCPR/C/21/Rev.1/Add.7 (1996), reprinted in Compilation of General Comments and General Recommendations Adopted by Human Rights Treaty Bodies, U.N. Doc. HRI/GEN/1/Rev.6 at 168 (2003) [hereinafter the General Comment 25], at para. 3 .

8 Id., at para. 3 .

9 Id., at para. 21 where the Committee holds that 'the Covenant does not impose any particular electoral system.'

${ }_{10}$ Id., at para. 1 . The express link between participatory rights and democracy has only been made by the Committee after the collapse of the Soviet bloc. The Committee considers that 'Article 25 lies at the core of democratic government based on the consent of the people and in conformity with the principles of the Covenant'. In the same document the Committee refers once to the 'democratic process' which may not be 'distorted' (para. 19). Marshall v. Canada, Communication No. 205/1986, U.N. Doc. CCPR/C/43/D/205/ 1986 at 40 (1991), was one of the first cases in which the Committee referred to the (need for a) 'democratic State' (at para. 5.5). In subsequent decisions, this has become common practice, e.g.: Debreczeny v. The Netherlands, Communication No. 500/1992, U.N. Doc. CCPR/C/53/D/500/1992 (1995), at paras. 4.2, 7.1, 7.3, and 9.3 (the 'democratic decision-making process'), and at para. 7.9 ('democratic decisionmaking procedures'), and at para. 8.4 ('democratic rules'). See also, e.g.: Robert W. Gauthier v. Canada, Communication No 633/1995, U.N. Doc. CCPR/C/65/D/633/1995 (5 May 1999) at para. 13.5; Dergachev v. Belarus, Communication No. 921/2000, U.N. Doc. CCPR/C/74/D/921/2000 (2002), at para. 2.3; YongJoo Kang v. Republic of Korea, Communication No. 878/1999, U.N. Doc. CCPR/C/78/D/878/1999 (2003), at para. 2.5; Kim Jong-Cheol v. Republic of Korea, Communication No. 968/2001, U.N. Doc. CCPR/ C/84/D/968/2001 (2005), at para. 8.3.

11 Cf. General Comment 25, at para. 7 (final sentence). 
specific aspect of participatory rights: indirect participation through genuine elections and indeed through exercising one's suffrage rights. ${ }^{12}$ The ICCPR's emphasis on suffrage rights, as the key towards enjoyment of the right to public participation, is perhaps not that remarkable when we compare it to other international human rights instruments and mechanisms. The European Convention on Human Rights does not itself contain any standards on public participation. ${ }^{13} \mathrm{~A}$ duty to organize regular elections was included into (article 3 of) the first Protocol to the ECHR, currently applicable to 45 out of the 47 Council of Europe member states:

The High Contracting Parties undertake to hold free elections at reasonable intervals by secret ballot, under conditions which will ensure the free expression of the opinion of the people in the choice of the legislature. ${ }^{14}$

Though formulated as a state obligation rather than an individual entitlement, this principle has been construed by the European Court of Human Rights so as to entail individual human rights standards that can be invoked by the individual before this Court. ${ }^{15}$ Still, on the face of it the difference in scope with article 25 UDHR/ICCPR is striking: a rather thin right to vote versus a general right and opportunity to take part in the conduct of public affairs, including direct participation. Some of these discrepancies (notably the omission of the right to run for public office $)^{16}$ have been tackled by the Court by means of an expansive reading of the cited provision.

As mentioned, universal suffrage in relation to (representative) public affairs bodies does not provide a genuine remedy for the adverse effects of privatisation, as it is the process of privatisation that affects what constitutes public affairs. Though the emphasis on suffrage rights in the ICCPR and the workings of the Human Rights Committee is undeniable, the right to take part in public affairs is more than a 'mere' right to vote. The question now is how far the ICCPR norms on direct public participation reach. The Human Rights Committee held that the conduct of 'public affairs' as referred to in article 25 of the ICCPR:

is a broad concept which relates to the exercise of political power, in particular the exercise of legislative, executive and administrative powers. It covers all aspects of public administration, and the formulation and implementation of policy at international, national, regional and local levels. The allocation of powers and the means by which individual citizens exercise the right to participate in the conduct of public affairs protected by article 25 should be established by the constitution and other laws. ${ }^{17}$

Thus, there is a clear nexus between the right to public participation - both the direct and the indirect dimensions of participatory rights - and the exercise of political power

\footnotetext{
12 See id., at paras. 1, 3-4, particularly 7-15, and 19-22 on voting rights. For individual communications in which the Committee has touched upon suffrage rights, see e.g.: Marie-Hélène Gillot v. France, Communication No. 932/2000, U.N. Doc. A/57/40 at 270 (2002); Istvan Mátyus v. Slovakia, Communication No. 923/2000, U.N. Doc. A/57/40 (Vol. II) at 257 (2002); Guido Jacobs v. Belgium, Communication No. 943/2000, U.N. Doc. CCPR/C/81/D/943/2000 (2004); Leonid Svetik v. Belarus, Communication No. 927/2000, U.N. Doc. CCPR/C/81/D/927/2000 (2004); Fongum Gorji-Dinka v. Cameroon, Communication No. 1134/2002, U.N. Doc. CCPR/C/83/D/1134/2002 (2005); Kim Jong-Cheol v. Republic of Korea, Communication No. 968/2001, U.N. Doc. CCPR/C/84/D/968/2001 (2005). For recently expressed concerns about the enjoyment of voting rights in state reporting procedures, see e.g. the following Concluding Observations: A/57/40 vol. I (2002) 36 at para. 75(10)[UK]; A/58/40 vol. I (2003) 45 at para. 80(8)[Luxembourg]; A/58/40 vol. I (2003) 56 at para. 82(6)[Portugal]; A/59/40 vol. I (2004) 35 at para. 67(19)[Colombia].

13 [European] Convention for the Protection of Human Rights and Fundamental Freedoms, ETS No. 5, 213 U.N.T.S. 222, 4 November 1950 (entered into force: 3 September 1953; [hereinafter also European Convention on Human Rights or ECHR].

14 Protocol to the Convention for the Protection of Human Rights and Fundamental Freedoms, ETS No. 9, 20 March 1952 (entry into force: 18 May 1954). Monaco and Switzerland have signed but not ratified this protocol.

${ }_{15}$ First held by the European Court of Human Rights in Mathieu-Mohin and Clerfayt v. Belgium, ECHR, (1987), Application no. 9267/81, 46-50.

16 E.g. Id. paras. 51-52, and in many subsequent judgments.

17 General Comment 25, at para. 5 (emphasis added).
} 
according to the Committee. ${ }^{18}$ As far as the above right to indirect participation is concerned (suffrage), the Committee stated the nexus with governmental power even more narrowly. ${ }^{19}$ Thus, overall, article 25 of the ICCPR protects the right to, in the words of the Committee, 'participation in the public political life of the nation' ${ }^{20}$ This means, among other things, that participatory rights in the ICCPR do not cover private employment matters such as the election of an employee to a private company's workcouncil. ${ }^{21}$ Nowak concludes for these reasons that '[i]n a parliamentary democracy based on separation of powers, the term "conduct of public affairs" is mainly limited to election of the legislative authority in conjunction with the commitment on the executive authority to observe parliamentary laws'.22

Notwithstanding this, the opportunity for citizens to participate directly in public affairs arguably goes beyond participation in legislative or executive bodies, despite the rather significant degree of discretion states have in designing forms of direct participation (see also sub-section 2.2, infra). According to the Human Rights Committee, citizens' right to participate directly in the conduct of public affairs can be realized through the following modalities: ${ }^{23}$

- By enabling citizens to exercise power as members of legislative bodies or by holding executive office;

- By enabling citizens to choose or change their constitution or decide public issues through a referendum or other electoral processes; or:

- By enabling citizens to take part in popular assemblies which have the power to make decisions about local issues or about the affairs of a particular community, and in bodies established to represent citizens in consultation with government (for these two modalities, see sub-section 2.2);

- The equality principle enshrined in article 2 of the ICCPR applies to these different modes of direct participation, meaning that the state may not make arbitrary distinctions between people when it comes to giving effect to direct participation. ${ }^{24}$

One important, though often exclusively emphasised aspect - arguably at the detriment of the other listed dimensions (see also sub-section 2.2) - of the opportunity to directly take part in the conduct of public affairs is the right to stand for elections. This passive political right is the other side of the coin of suffrage rights. This notably involves a right to stand for parliamentary elections, though the right equally applies to all 'elective offices' according to the Human Rights Committee. ${ }^{25}$ What is striking in the Committee's inventory is that the citizens' right to participate directly in the conduct of public affairs must also be realised by enabling them to hold executive office. This guarantee is stronger than the standards on political rights provided by, for instance, the European Convention on Human Rights. Though article 3 of the Protocol to the ECHR does not explicitly provide for a right to stand for elections, this right has been read into the provision by the European Court of Human Rights. ${ }^{26}$ However, the European Court of Human Rights has repeatedly argued that article 3 of the Protocol only applies to the

Cf. Id. at para. 5.

9 Id., para. 7.

Mümtaz Karakurt v. Austria, Communication No. 965/2000, U.N. Doc. CCPR/C/74/D/ 965/2000 (2002), para. 8.2

21 Precisely what Karakurt v. Austria, Id., revolved around.

Nowak, above n. 4, at 570-571.

General Comment 25, para. 6 .

Id.

The Committee devotes paras. 15-18 of General Comment 25 to the right to stand for elective offices.

6 See, e.g., Mathieu-Mohin and Clerfayt v. Belgium, ECHR, (1987), Application no. 9267/81, 51; Melnychenko v. Ukraine, ECHR, (2004), Application No. 17707/02, para. 54; Ždanoka v. Latvia, ECHR, (2006), Application No. 58278/00, 102; Sejdić and Finci v. Bosnia and Herzegovina, ECHR, (2009), Applications Nos. 27996/06 and 34836/06, 50. However, cases concerning the dissolution of political parties (e.g. the series of European Court of Human Rights jurisprudence on the dissolution of political parties in Turkey) tend to be discussed under Article 11 of the ECHR on freedom of association. 
'legislator'. ${ }^{27}$ This means that under the European Convention system individual claims concerning illegitimate obstacles or discriminatory bars to eligibility to hold executive office cannot be scrutinized in light of Article 3 of the aforementioned Protocol. ${ }^{28}$ In any event, in both the view of the Human Rights Committee and the European Court of Human Rights, the right to stand for elections is intended to enable participation in governmental bodies. The difference between the two approaches is that for the Human Rights Committee, the right to stand for elections is not the only imaginable means of enjoying one's right to actively take part in the conduct of public affairs.

The caveats that apply to suffrage apply equally to the right to run for public office: it offers only a limited potential to remedy the effects of privatisation, as processes of privatisation unabatedly expropriate public offices' core business: public affairs.

Thus far, the specific (equal) right to have access to public service in one's country has not been addressed. Article 25(c) of the ICCPR, reiterating a similar formula enshrined in the UDHR, deals with the opportunity of citizens to have access, upon general terms of equality, to public service positions. The case law of the Human Rights Committee revolves predominantly around (dismissal from) civil servant positions. It is interesting to note that 'public service positions' are not in actual fact defined by the ICCPR ${ }^{29}$ Processes of globalisation and privatisation might, in other words, also affect this specific dimension of participatory rights. Starting with the former process, it is not at all certain that positions in inter-governmental organizations can engage protection of article 25. In H. v. The Netherlands, the Committee declared a complaint about alleged ill-treatment of the applicant by the European Patent Office to be inadmissible as this issue was not subject to the jurisdiction of the Netherlands (and hence did not come within the monitoring jurisdiction of the Committee).$^{30}$

Turning to the issue of privatisation, as neither the ICCPR nor the workings of the Human Rights Committee pinpoints what constitutes a civil servant position, there is a risk that only clear-cut legislative, executive and judiciary positions will automatically engage protection by article 25(c) of the ICCPR. Beyond the realm of these positions, as Nowak observes, '[i]t depends on the national legal system whether public service includes other posts attributable to the State where a person is appointed under a private contract or exercises non-executive functions. This particularly applies to posts in

\footnotetext{
27 For an elaboration of what constitutes the legislature in the view of the European Court of Human Rights, see R.C.A. White and C. Ovey, The European Convention on Human Rights (2010), at 522-523.

28 E.g.: in Sejdić and Finci v. Bosnia and Herzegovina, ECHR, (2009), Applications Nos. 27996/06 and $34836 / 06$, the European Court of Human Rights deals with allegations of discrimination concerning the possibility of holding the office of the Presidency of the Republic under Article 1 of Protocol No. 12 to the ECHR, which provides for a general non-discrimination principle. In the aforementioned case, the two applicants contested the ineligibility (on grounds of their Roma and Jewish origin) to stand for election to both the House of Peoples (which was considered a legislative body) and the office of Presidency.

29 The Human Rights Committee in its relevant General Comment and Views on individual communications has, however, elaborated that equal access implies that the criteria and processes for appointment, promotion, suspension and dismissal must be objective and reasonable, that affirmative measures may be taken in appropriate cases to ensure that there is equal access to public service for all citizens, and that there may no discrimination on the ground of political opinion or expression. See General Comment 25, at paras. 23-25. See also, e.g., Adimayo M. Aduayom, Sofianou T. Diasso and Yawo S. Dobou v. Togo, Communications Nos. 422/1990, 423/1990 and 424/1990, U.N. Doc. CCPR/C/51/D/422/1990, 423/1990 and 424/1990(1996), para. 7.5

30 H. v. The Netherlands, Communication No. 217/1986, U.N. Doc. CCPR/C/OP/2 at 70 (1990). The European Court of Human Rights, considering the fact that the ECHR does not contain relevant provisions that provide protection to civil servants, and considering the fact that international organizations themselves will often enjoy immunities before domestic courts, has opted to assess this type of cases (concerning the legal position of international civil servants) in light of the right to access to a court (or more generally the right to have one's case heard) and the right to an effective remedy. In such cases as Waite and Kennedy v. Germany, ECHR, (2009), Application No. 26083/94; and Beer and Regan v. Germany, ECHR, (2009), Application no. 28934/95, the Court formulated its 'reasonable alternative means' test (resp. para. 68 and 58), meaning that a domestic court granting full immunity to the international organization at hand (for instance in cases revolving around ill-treatment of employees) does not act contrary to the ECHR only if reasonable alternative means, such as review or appeals boards within the international organization itself, were available to effectively protect the rights under the ECHR. For a comprehensive analysis, see C. Ryngaert, 'The Immunity of International Organizations Before Domestic Courts: Recent trends', 7(1) International Organizations Law Review (2010), at 132-144.
} 
State schools, universities, broadcasting authorities or other State undertakings and services'. ${ }^{31}$ Thus, two scenarios may affect the scope of protection offered by article 25(c) of the ICCPR: (i) certain positions de facto revolving around providing public servicers may, under certain domestic legal systems, de jure not be regarded as 'public service positions'; and (ii) present public service positions may lose that status through processes of privatisation. With respect to the first instance, it stands to reason that the Human Rights Committee is in a position to autonomously determine that a position is of a public nature should a domestic label be at odds with the objectively public nature of this position. As for the second scenario, to the extent that the public value of the service is indeed at stake, the state will be under a due diligence obligation to ensure that equal and appropriate access is guaranteed by the new provider. ${ }^{32}$

Once more the previous caveat can be reiterated: the right to have access to the public service offers only a limited potential to remedy the effects of privatisation, as processes of privatisation also affect the public service in so far as 'public affairs' are expropriated from it.

\subsection{Participation in Decision-Making Beyond the Realm of Suffrage or the Right to Run for Public Office: An Answer to Privatisation?}

Returning to the Human Rights Committee's inventory of the modalities of active participation in the conduct of public affairs, the question remains as to how far positive state obligations to enable citizens to directly participate in public affairs extend. How far does the citizens' right to choose or change their constitution or to decide public issues through a referendum or other decision-making processes stretch $?^{33}$ How far is the reach of the positive obligation to enable citizens to take part in popular assemblies that have the power to make decisions about local issues or about the affairs of a particular community, or the right to take part in bodies established to represent citizens in consultation with government? $?^{34}$ It is the latter opportunity and corresponding state obligation in particular, that would appear particularly pertinent in times of privatisation.

In Marshall v. Canada, the authors of the communication to the Human Rights Committee complained that they, the representatives of the Mikmaq people, were not invited to attend the constitutional conferences on aboriginal matters. ${ }^{35}$ More particularly, Grand Chief Donald Marshall (et al.) was of the opinion that the refusal on the part of the Prime Minister of Canada to permit specific representation for the Mikmaqs at the constitutional conferences was tantamount to a violation of the right to take part in the conduct of public affairs. Constitutional conferences, in the view of the Committee, constituted 'conduct of public affairs' within the meaning of article 25 of the ICCPR.$^{36}$ In an attempt to determine the precise scope of the right of every citizen to take part in the conduct of public affairs, the Committee commenced by pointing out that '[s]urely, it cannot be the meaning of article 25(a) of the Covenant that every citizen may determine either to take part directly in the conduct of public affairs or to leave it to freely chosen representatives. It is for the legal and constitutional system of the State party to provide for the modalities of such participation' ${ }^{37}$ In other words, participatory rights under the ICCPR do not entail a choice on the part of the beneficiary of these rights as to how one's right to public participation is best guaranteed in any specific case. Rather, a state party discharges its obligations if it ensures that adequate modalities of public participation are generally in place. Turning to the alleged violation of the Mikmaq people's right to (directly) take part in the conduct of public affairs, the Committee concluded:

Nowak, above n. 4, at 586

32 Cf., mutatis mutandis, Robert W. Gauthier v. Canada, Communication No 633/1995, U.N. Doc. CCPR/ C/65/D/ 633/1995 (5 May 1999), as outlined below (section 2.2).

33 Forms of direct participation are mentioned in General Comment 25, at para. 6.

34 Id.

5 Marshall v. Canada, Communication No. 205/1986, U.N. Doc. CCPR/C/43/D/205/1986 at 40 (1991).

36 Id., para. 5.3.

37 Id., para. 5.4. 
It must be beyond dispute that the conduct of public affairs in a democratic State is the task of representatives of the people, elected for that purpose, and public officials appointed in accordance with the law. Invariably, the conduct of public affairs affects the interest of large segments of the population or even the population as a whole, while in other instances it affects more directly the interest of more specific groups of society. Although prior consultations, such as public hearings or consultations with the most interested groups may often be envisaged by law or have evolved as public policy in the conduct of public affairs, article 25(a) of the Covenant cannot be understood as meaning that any directly affected group, large or small, has the unconditional right to choose the modalities of participation in the conduct of public affairs. That, in fact, would be an extrapolation of the right to direct participation by the citizens, far beyond the scope of article $25(a){ }^{38}$

Thus the Committee concludes that, notwithstanding the right of every citizen to take part in the conduct of public affairs without discrimination and without unreasonable restrictions, the failure of Canada to invite representatives of the Mikmaq tribal society to the constitutional conferences on aboriginal matters did not breach the participatory rights of members of the Mikmaq tribal society.

This conclusion begs the question: under what circumstances will the state be found to have acted contrary to the right to take part in the conduct of public affairs when forms of direct participation are at stake? After all, it was not the Mikmaq tribal society that has undertaken to 'choose the modalities of participation', as Canada had done this already. It was the Canadian Constitution Act itself that envisaged a process which would include constitutional conferences to be convened by the Prime Minister of Canada and attended by the first ministers of the provinces and invited 'representatives of the aboriginal peoples of Canada'. ${ }^{39}$ Several such conferences indeed have been convened by the Prime Minister of Canada. These constitutional conferences were generally only open for elected leaders of the federal and provincial governments; however, the conferences specifically dealing with aboriginal matters (such as the one at hand) formed an exception to this rule as they 'focused on the matter of aboriginal self-government and whether and in what form, a general aboriginal right to self-government should be entrenched in the Constitution of Canada' ${ }^{40}$ In sum, the state itself, through statutory law, had accepted that certain identified stakeholders could utilise direct modes of participation, in this case through consultation. Thus, in light of the specifics of the case, the Committee's view that there did not exist a right to direct participation in abstracto is beside the point, since that right existed in Canada and, moreover, it existed specifically for this type of situation, where public decisions could affect the rights, interests and legal position of the tribal society at stake. Regardless of whether a right to direct participation in abstracto exists in every state or not, in cases such as the one at hand this right existed in concreto, given the specific circumstances of the case and the legitimate interests of stakeholders to be directly included in decision-making processes that may have affected their rights or legal status.

The Committee's view grants states parties a large degree of discretion to discharge ICCPR obligations in the field of public participation. The approach taken by the Human Rights Committee is perhaps understandable from the perspective of the subsidiarity principle, here used in the meaning that every sovereign state under international law is largely free to decide on its own internal system of political organization. This also means that states generally have a fairly free hand in deciding on the appropriate means to comply with their obligations flowing from international law. The Committee's approach is perhaps also understandable given the fact that article 25 uses the word 'or' in paragraph (a). Nowak argues in this respect:

38 Id., para. 5.5 (emphasis added).

39 Id., para. 2.2 .

40 Id. The fact that these conferences were ultimately inconclusive and that no consensus was reached on possible constitutional amendments does not detract from the ultimate importance of participation in such a process. 
... States parties are not required to create possibilities for participation by plebiscite. This does not, however, mean that the reference to direct participation is of no significance. It has the effect of giving citizens an individual right to take part in referendums and similar consultations when these are provided for by the State party... while required to hold periodic elections, the States parties are not required to conduct public consultations, such as referendums and plebiscites. ${ }^{41}$

Be that as it may, the Committee's approach remains problematic when it results in genuine stakeholders being marginalized as was the case in the above example. Moreover, in times of privatisation, the right to take part in public affairs naturally cannot be expected to be fully realized 'through freely chosen representatives'. Thus, construing ICCPR standards on public participation so as to impose a generic, abstract duty upon the state to guarantee the right to public participation through indirect modalities, with the main emphasis on free elections, could fall short of affording appropriate protection.

The question is whether the Committee's decision in the Mikmaq tribal society case signifies that a concrete right to direct participation is altogether out of the question. ${ }^{42}$ If that is indeed the lesson to be drawn here, the Committee has shot itself in the foot by taking that approach, and - if it were to stick to that approach - one may not expect the Committee to be in a position to adequately face the challenge posed by privatisation to the right to public participation.

The Committee has, albeit very indirectly, had the opportunity to demonstrate its abilities in dealing with the issue of privatisation in other areas (some of which touch upon public participation), and in such cases the approach taken appeared more satisfactory. In Gauthier v. Canada, the Committee's views were solicited concerning the compatibility with the ICCPR of a particular accreditation scheme for access to the precincts of Parliament. ${ }^{43}$ As such, the case did not directly revolve around the issue of public participation. The applicant claimed that the denial of equal access to press facilities in Parliament constituted a violation of his rights under article 19 of the Covenant: the freedom to seek and receive information. ${ }^{44}$ However, as the Committee pointed out in this case, the freedom to seek and receive information must be read in conjunction with the right to take part in the conduct of public affairs (article 25 of the ICCPR). ${ }^{45}$ Also in its General Comment No. 25 (on public participation) the Committee makes the connection between the two fundamental rights several times. ${ }^{46}$ Article 25 and 19 read together imply that 'citizens, in particular through the media, should have wide access to information and the opportunity to disseminate information and opinions about the activities of elected bodies and their members'. ${ }^{47} \mathrm{Mr}$ Gauthier, who worked as a publisher of the National Capital News, had his freedom to seek and receive information restricted, as he was provided with a temporary pass that gave only limited

41 Nowak, above n. 4, at 571-572 (emphasis added).

42 Alternatively, it could be suggested that the Committee was not convinced that the particulars of this case warranted the engagement of this right. However, the quoted excerpts seem to go much beyond this, dismissing the usage of this right as a matter of principle. As previously mentioned, the conclusion of this case may cause one to question what circumstances could possibly merit engagement of the right to be involved in the decision-making process.

43 Gauthier v. Canada, above n. 32.

44 Though some Committee Members were of the opinion that the case should have been examined in light of Articles 22 and 26 (respectively on freedom of association and equality before the law). See the different individual opinions appended to the case.

45 Gauthier v. Canada, above n. 32, at para. 13.4.

46 General Comment 25, at para. 26: 'In order to ensure the full enjoyment of rights protected by Article 25 , the free communication of information and ideas about public and political issues between citizens, candidates and elected representatives is essential. This implies a free press and other media able to comment on public issues without censorship or restraint and to inform public opinion. It requires the full enjoyment and respect for the rights guaranteed in Articles 19, 21 and 22 of the Covenant, including freedom to engage in political activity individually or through political parties and other organizations, freedom to debate public affairs, to hold peaceful demonstrations and meetings, to criticize and oppose, to publish political material, to campaign for election and to advertise political ideas'. See also paras. 8 and 12.

${ }^{47}$ Gauthier v. Canada, above n. 32, at para. 13.4. 
privileges and limited access to the precincts of Parliament. The peculiarity of this case lies in the fact that the entity administering the accreditation for access to the precincts of Parliament was a private association called the Parliamentary Press Gallery. Faced with several contradictory statements by the state on the exact relationship between the Speaker of the House of Parliament and the Parliamentary Press Gallery, the Committee ultimately endorsed the view that ' $[\mathrm{w}]$ hile the Speaker has ultimate authority over the physical access to the media facilities in Parliament, he is not involved in the general operations of these facilities which are administered and run entirely by the Press Gallery'. ${ }^{48}$ The Committee ultimately held that:

In the instant case, the State party has allowed a private organization to control access to the Parliamentary press facilities, without intervention. The scheme does not ensure that there will be no arbitrary exclusion from access to the Parliamentary media facilities. In the circumstances, the Committee is of the opinion that the accreditation system has not been shown to be a necessary and proportionate restriction of rights within the meaning of article 19, paragraph 3, of the Covenant, in order to ensure the effective operation of Parliament and the safety of its members. The denial of access to the author to the press facilities of Parliament for not being a member of the Canadian Press Gallery Association constitutes therefore a violation of article 19 (2) of the Covenant. ${ }^{49}$

In sum, contracting out a (public) service to a private organisation, or in the words of the Committee, allowing a private organisation to be in control, does not relieve the state from its responsibilities under human rights law when public values are at stake. ${ }^{50}$

\subsection{Post-Bill of Rights Participatory Rights: Answers to Privatisation?}

At the same time, other international human rights treaties, both universal and regional ones ${ }^{51}$ provide for specific participatory rights. The preamble of the Convention on the Elimination of All Forms of Discrimination against Women makes it clear that one of the principal objectives of this UN treaty is to maximize the participation of women in the political, social, economic and cultural life of their countries. ${ }^{52}$ Participatory rights in CEDAW are much more than entitlements or opportunities to take part in

\footnotetext{
$48 \quad$ Id., para. 11.2 (emphasis added).

$49 \quad$ Id., para. 13.6

50 The latter caveat also shows the limitations of the relevant rights: if no public values whatsoever are at stake there can be no state obligation, and consequently no potential violation of due diligence. One may recall private employment matters such as the election of an employee to a private company's workcouncil, as was the case in Karakurt v. Austria, above n. 20.

${ }_{51}$ As far as regional human rights organizations and instruments are concerned, Article 3 of the first Protocol of the ECHR (applicable to most Council of Europe member states) has been discussed above. At this point it should be added that participatory rights have been codified within the framework of both the Organization of American States and the African Union. See Article 23 of the American Convention on Human Rights, O.A.S.Treaty Series No. 36, 1144 U.N.T.S. 123, entered into force 18 July 1978, reprinted in Basic Documents Pertaining to Human Rights in the Inter-American System, OEA/Ser.L.V/II.82 doc.6 rev.1 at 25 (1992); and Article 13 of the African Charter on Human and Peoples' Rights, adopted 27 June 1981, OAU Doc. CAB/LEG/67/3 rev. 5, 21 I.L.M. 58 (1982), entered into force 21 October 1986. Both provisions are largely comparable to ICCPR's equivalent provision. Having said that, the Inter-American provision on participation provides for an explicit limitation clause, whereas the ICCPR and European equivalents make use of 'implied restrictions' that have been developed by the Human Rights Committee and the European Court of Human Rights (Article 3 of the Protocol to the ECHR does not mention any possibility of limitation, whilst Article 25 ICCPR merely uses the words 'without unreasonable restrictions'). As for the equivalent African provision, it is interesting to note that an equal 'right of access to public property' is incorporated into the provision on public participation.

52 See the two references to participation in the preamble of the Convention on the Elimination of All Forms of Discrimination against Women, G.A. res. 34/180, 34 U.N. GAOR Supp. (No. 46) at 193, U.N. Doc. A/34/46, entered into force 3 September 1981 [hereinafter CEDAW]. CEDAW has been ratified by 186 states (Israel and Monaco have entered partial reservations to Article 7, whilst a number of states have entered sweeping -religious- reservations to CEDAW in its entirety).
} 
political affairs. The traditional right to public participation can be found in article 7 of CEDAW which guarantees women's rights to 'vote in all elections and public referenda and to be eligible for election to all publicly elected bodies' and 'to participate in the formulation of government policy and the implementation thereof and to hold public office and perform all public functions at all levels of government'. ${ }^{53}$ However, particularly the latter provision (Article 7(b) of CEDAW) seems to go significantly beyond the requirements of the aforementioned general standards on governmental participation, implying a more general right to participation in relevant decision-making processes. The Committee on the Elimination of Discrimination against Women holds that CEDAW requires states parties:

... to ensure that women have the right to participate fully in and be represented in public policy formulation in all sectors and at all levels. This would facilitate the mainstreaming of gender issues and contribute a gender perspective to public policy-making...States parties have a responsibility, where it is within their control, both to appoint women to senior decisionmaking roles and, as a matter of course, to consult and incorporate the advice of groups which are broadly representative of women's views and interests. ${ }^{54}$

The Committee has further elaborated upon possible measures that could be adopted to ensure equal participation by women in senior cabinet and administrative positions and as members of government advisory bodies:

... adoption of a rule whereby, when potential appointees are equally qualified, preference will be given to a woman nominee; the adoption of a rule that neither sex should constitute less than 40 per cent of the members of a public body; a quota for women members of cabinet and for appointment to public office; and consultation with women's organizations to ensure that qualified women are nominated for membership in public bodies and offices and the development and maintenance of registers of such women in order to facilitate the nomination of women for appointment to public bodies and posts. ${ }^{55}$

With regard to direct participation through advisory bodies, the Committee considered that ' $[\mathrm{w}]$ here members are appointed to advisory bodies upon the nomination of private organizations, States parties should encourage these organizations to nominate qualified and suitable women for membership in these bodies' ${ }^{56}$ This constitutes a clear due diligence obligation. The Committee has consequently acknowledged the fact that different national systems vary in their treatment of the public/private divide, and that as such, respective processes of privatisation could undermine the potential of direct participation.

Women enjoy a range of additional, varying participatory rights pursuant CEDAW:

- the right to participate in non-governmental organizations and associations concerned with the public and political life of the country;

- the opportunity to represent their Governments at the international level and to participate in the work of international organizations;

- equal opportunities to participate actively in sports and physical education;

- the right to participate in recreational activities, sports and all aspects of cultural life;

53 Article 7(a) and (b) of CEDAW.

54 Paras. 25-26 (emphasis added) Committee on the Elimination of Discrimination against Women, General Recommendation 23: Political and Public Life (Sixteenth session, 1997), U.N. Doc. A/52/38/Rev.1 at 61 (1997), reprinted in Compilation of General Comments and General Recommendations Adopted by Human Rights Treaty Bodies, U.N. Doc. HRI/GEN/1/Rev.6 at 260 (2003). Subsequent paragraphs (27-28) specify women's right to participation in government.

55 Id. para. 29.

56 Id. 
- the right to participate in the elaboration and implementation of development planning at all levels;

- and the right to participate in all community activities. ${ }^{57}$

In addition, CEDAW prescribes the following positive obligations to states parties:

- to encourage the provision of the necessary supporting social services to enable parents to combine family obligations with work responsibilities and participation in public life, in particular through promoting the establishment and development of a network of child-care facilities;

- to take all appropriate measures to eliminate discrimination against women in rural areas in order to ensure that women participate in and benefit from rural development (which also includes guarantees to the earlier mentioned right to participate in the elaboration and implementation of development planning at all levels and the right to participate in all community activities). ${ }^{58}$

The International Convention on the Elimination of All Forms of Racial Discrimination (whose adoption predates the ICCPR's) already included participatory rights, albeit with a clear focus on political participation proper. It includes in particular: the right to participate in elections, the right to vote and to stand for election, and the rights to take part in the government as well as in the conduct of public affairs at any level and to have equal access to public service. ${ }^{59}$ In addition, CERD enshrines a specific right to equal participation in cultural activities ${ }^{60}$ a right also adopted by the International Covenant on Economic, Social and Cultural Rights. ${ }^{61}$ The Committee on the Elimination of Racial Discrimination has emphasised that states parties to CERD must especially ensure that 'members of indigenous peoples have equal rights in respect of effective participation in public life and that no decisions directly relating to their rights and interests are taken without their informed consent' ${ }^{62}$ The notion can certainly be welcomed from a human rights perspective: it offers far-reaching protection and goes significantly beyond the views of the Human Rights Committee that have rejected such a concrete right to direct public participation.

It is striking that the Committee on the Elimination of Racial Discrimination requires stakeholders' informed consent (rather than mere informed participation) in all areas where stakeholders' rights are to be considered in a decision-making processes. The Committee on the Elimination of Racial Discrimination has quite extensively engaged with this notion, for instance through the state reporting procedure, by repeatedly highlighting concerns about state practice. In this respect the Committee has, for instance, noted and considered the following:

- The failure of the Costa Rican authorities to maintain communication with the indigenous population was seen as a matter of concern. As a result, the Committee called upon Costa Rica 'to ensure that members of indigenous

\footnotetext{
57 See Articles 7(c), 8, 13(c), 14(2)(a) and (f), of CEDAW.

58 Article 11(2)(c), 14(2), of CEDAW.

59 Article 5(c) of the International Convention on the Elimination of All Forms of Racial Discrimination, G.A. res. 2106 (XX), Annex, 20 U.N. GAOR Supp. (No. 14) at 47, U.N. Doc. A/6014 (1966), 660 U.N.T.S. 195, entered into force 4 January 1969 [hereinafter CERD].

${ }^{60}$ Article 5(e)(vi) of CERD. Both rights are listed as areas in which racial discrimination ought to be eradicated.

${ }_{61}$ See Article 15(1)(a) of the International Covenant on Economic, Social and Cultural Rights, G.A. res. 2200A (XXI), 21 U.N.GAOR Supp. (No. 16) at 49, U.N. Doc. A/6316 (1966), 993 U.N.T.S. 3, entered into force Jan. 3, 1976. This Covenant also considers that the right to education has participatory value in so far as promotion of the right of everyone to education 'shall enable all persons to participate effectively in a free society' (Article 13).

62 General Recommendation 23: Rights of Indigenous Peoples (Fifty-first session, 1997), U.N. Doc. A/52/18, annex V at 122 (1997), reprinted in Compilation of General Comments and General Recommendations Adopted by Human Rights Treaty Bodies, U.N. Doc. HRI GEN \1\Rev.6 at 212 (2003) (emphasis added), at para. 4
} 
peoples have equal rights in respect of effective participation in public life and that no decisions directly relating to their rights and interests are taken without their informed consent'; ${ }^{63}$

- With respect to Botswana, the Committee expressed consternation regarding the discriminatory character of certain domestic laws, particularly the Chieftainship Act and the Tribal Territories Act which only recognize the Tswana-speaking tribes. As a consequence, other tribes do not enjoy their rights to public participation (for instance, they cannot participate in the House of Chiefs) $;{ }^{64}$

- With regard to New Zealand, the Committee pointed out that it remained 'concerned about the continuing disadvantages that Maori, Pacific Island people and other ethnic communities face in the enjoyment of social and economic rights, such as the rights to employment, housing, social welfare, and health care. The State party is invited to...encourage active and effective participation by Maori in the search for solutions such as the Maori Mental Health Strategic Framework adopted in May 2002, with a view to further reducing these disadvantages', ${ }^{65}$

- In relation to Saint Lucia, the Committee notes that the constitutional requirement to speak and read English "curtails the right of the indigenous population, the majority of whom are fluent only in Kweyol, to participate in political elections'; ${ }^{66}$

- The Traveller community cannot effectively participate in the conduct of public affairs in Ireland, as they are not adequately recognized or represented in the Irish political institutions. ${ }^{67}$

From the above, it can be concluded that the Committee on the Elimination of Racial Discrimination requires from states parties precisely the type of ad hoc consultation that the Human Rights Committee refused to accept in the case concerning the Mikmaq tribal society. This approach aims to ensure that no decisions directly relating to stakeholders' rights and interests are taken without their informed consent. ${ }^{68}$

The recently adopted Declaration on the Rights of Indigenous Peoples also devotes ample attention to the right to public participation. ${ }^{69}$ This (as yet non-binding) Resolution

$\mathrm{A} / 57 / 18$ (2002) 21 at para. 76 [Costa Rica].

64 The Committee expressed particular concern regarding some of the consequences of these shortcomings: 'the ongoing dispossession of Basarwa/San people from their land and...their [reported] resettlement outside the Central Kalahari Game Reserve does not respect their political, economic, social and cultural rights. The Committee... recommends that no decisions directly relating to the rights and interests of members of indigenous peoples be taken without their informed consent': A/57/18 (2002) 53 at paras. 301 and 304 [Botswana].

65 A/57/18 (2002) 69 at para. 422 [New Zealand].

${ }_{66} \mathrm{~A} / 59 / 18$ (2004) 86 at para. 446 [Saint Lucia].

67 A/60/18 (2005) 30 at para. 146 [Ireland].

68 Marshall v. Canada, above n. 10. In relation to CERD, it may finally be noted that the Committee on the Elimination of Racial Discrimination has been particularly active in promoting the participatory rights of Roma minorities. See para. 41-46 of General Recommendation 27: Discrimination against Roma (Fiftyseventh session, 2000), U.N. Doc. A/55/18, annex V at 154 (2000), reprinted in Compilation of General Comments and General Recommendations Adopted by Human Rights Treaty Bodies, U.N. Doc. HRI GEN $\backslash 1 \backslash$ Rev.6 at 216 (2003). In General Recommendation 22: Refugees and Displaced Persons (Fortyninth session, 1996), U.N. Doc. A/51/18, annex VIII at 126 (1996), reprinted in Compilation of General Comments and General Recommendations Adopted by Human Rights Treaty Bodies, U.N. Doc. HRI GEN $\backslash 1 \backslash$ Rev.6 at 211 (2003), the Committee promoted the rights of another particularly vulnerable group arguing that all 'refugees and displaced persons have, after their return to their homes of origin, the right to participate fully and equally in public affairs at all levels and to have equal access to public services and to receive rehabilitation assistance' (para. 2, (d)). See also General Recommendation 29: Discrimination Based on Descent (Sixty-first session, 2002), U.N. Doc. A/57/18 at 111 (2002), reprinted in Compilation of General Comments and General Recommendations Adopted by Human Rights Treaty Bodies, U.N. Doc. HRI $\backslash$ GEN $\backslash 1 \backslash$ Rev.6 at 223 (2003), in which the Committee emphasised the participation rights of those groups of people affected by discrimination based on descent (see paras. 1(e), 6 (bb), and 6 (cc)).

69 Declaration on the Rights of Indigenous Peoples, G.A. Res. 61/295,U.N. Doc. A/RES/47/1 (2007). 
holds that: 'Indigenous peoples have the right to maintain and strengthen their distinct political, legal, economic, social and cultural institutions, while retaining their right to participate fully, if they so choose, in the political, economic, social and cultural life of the State'. ${ }^{70}$ The Declaration, going beyond general political participatory rights (suffrage etc.), emphasises that indigenous peoples 'have the right to participate in decision-making in matters which would affect their rights, through representatives chosen by themselves in accordance with their own procedures, as well as to maintain and develop their own indigenous decision-making institutions' ${ }^{71}$ Also at the concrete level of indigenous peoples' rights, substantive freedoms or other standards are mainstreamed with participatory rights. For instance, in the area of land and property, the Declaration requires that states shall establish a fair, independent, impartial, open and transparent process in order to recognise and adjudicate indigenous peoples' land and property claims. Establishing such a system ensures that indigenous peoples shall have the right to participate in this process. ${ }^{72}$ Ensuring participation of indigenous peoples on the adjudication of issues affecting them is also to be mainstreamed by any UN initiative adopted for the purposes of realising the standards set out by the Declaration. ${ }^{73}$

For obvious reasons, the Convention on the Rights of the Child (CRC) does not enshrine general political participatory rights; however, certain specific rights to participation going beyond the traditional nexus with government and policy-making are codified. ${ }^{74}$ The overarching standard on children's participation is enshrined in article 12 of the CRC, which prescribes a degree of respect for the views and feelings of the child. This provision holds that a child "who is capable of forming his or her own views' has 'the right to express those views freely in all matters affecting the child, the views of the child being given due weight in accordance with the age and maturity of the child'.

In addition to this general principle, more specific participatory rights are recognized, such as the norm holding that all interested parties - including the child - shall be given an opportunity to participate in the proceedings and make their views known in cases that revolve around potential separation of children from their parents. ${ }^{75}$ Children, too, enjoy the right to participate freely in cultural life and the arts. ${ }^{76}$ The Committee on the Rights of the Child has furthermore emphasised and mainstreamed certain dimensions of children's participatory rights in its workings, such as the child's opportunity and right to participate in school life, ${ }^{77}$ children's participation in national human rights institutions and NGOs; ${ }^{.7}$ children's right to participate in raising awareness by speaking out about the impact of HIV/AIDS on their lives and in the development of HIV/AIDS policies and programmes; ${ }^{79}$ adolescents' right to participate in decisions affecting their health (notably through informed consent and the right of confidentiality) $;^{80}$ and a right of the child to effective participation in (criminal) legal proceedings that affect him

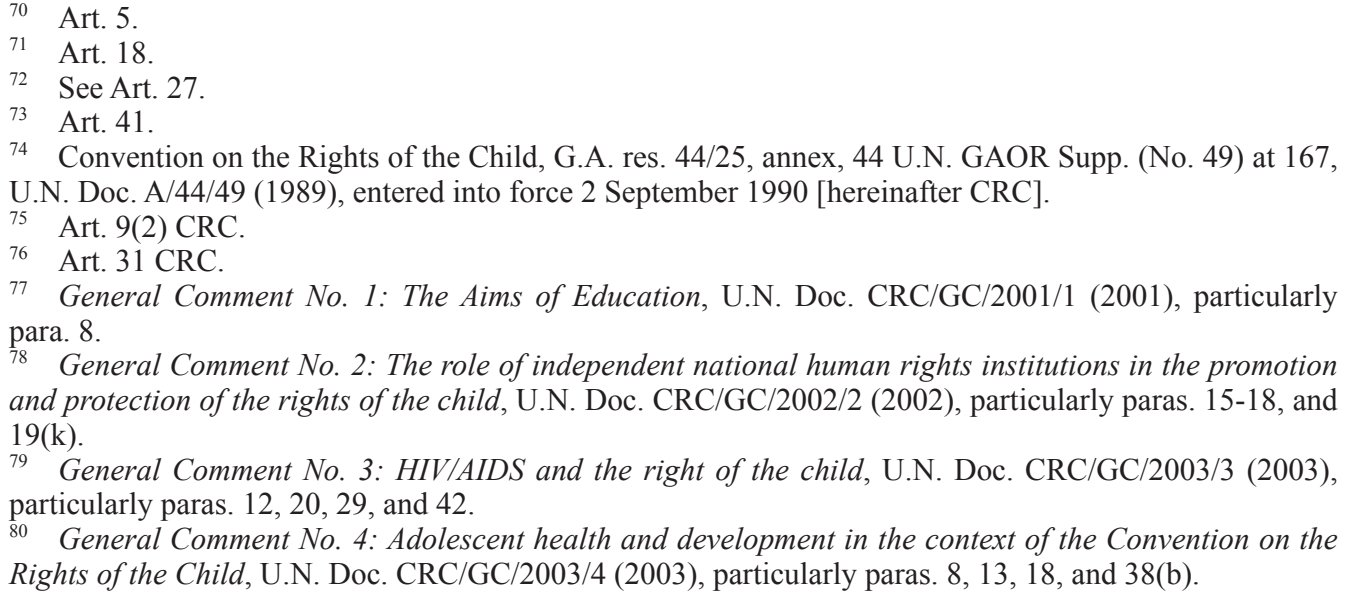


or her. ${ }^{81}$ CRC finally emphasises that states parties must try to facilitate mentally or physically disabled children's active participation in the community. ${ }^{82}$

The very rationale of the International Convention on the Protection and Promotion of the Rights and Dignity of Persons with Disabilities centres on fostering full and effective participation of persons with disabilities in society on an equal basis with others. ${ }^{83}$ Extensive public participation rights are encompassed in article 29 of this Convention. This includes not only the standard suffrage rights and the right to run for public office, but also more specific duties aiming to ensure an 'environment in which persons with disabilities can effectively and fully participate in the conduct of public affairs' ${ }^{84}$ These rights are also expressly extended to participation in NGOs and 'associations concerned with the public and political life of the country'. ${ }^{85}$ Measures to secure the participation of persons with disabilities further include rights to take part in cultural life ${ }^{86}$ rights to overall accessibility of the public space $;{ }^{87}$ participation in the community; ${ }^{88}$ access to education, including a right to benefit from education in order to participate effectively in a free society; ${ }^{89}$ and participation in the monitoring process of rights of persons with disabilities, at both the national level as well as the international (UN) level. ${ }^{90}$

The International Convention on the Protection of the Rights of All Migrant Workers and Members of Their Families contains a political participation clause (which boils down to a right to public participation in one's state of origin, not in the state of employment) ${ }^{91}$ and some provisions that extend beyond political participation. This convention prescribes, for instance, that states of employment must facilitate the consultation or participation of migrant workers and members of their families in decisions concerning life and administration in local communities. ${ }^{92}$

In sub-section 2.1 (above) it was stated that the right to public participation has traditionally been rather tightly linked with the exercise of governmental power; that is, participatory rights encompassing a right to engage, actively or passively, in politics. In this sub-section it has been noted that a number of specialised human rights conventions have broadened the scope of participatory rights considerably, although the question still remains as to whether such expansion has sufficiently equipped the international human rights machinery in order to face the challenge posed by privatisation.

Indeed, virtually all UN core human rights conventions have broadened the scope of participatory rights beyond the realm of democratic rights. In addition, virtually all treaty-monitoring bodies have commenced mainstreaming participatory rights with

\footnotetext{
${ }^{81}$ General Comment No. 10: Children's rights in juvenile justice (Forty-fourth session, 2007), U.N. Doc. $\mathrm{CRC} / \mathrm{C} / \mathrm{GC} / 10$ (2007).see particularly para. 46.

82 Art. 23(1) CRC. Further elaborated upon by the Committee on the Rights of the Child in General Comment No. 9: The rights of children with disabilities (Forty-third session, 2007), U.N. Doc. CRC/C/GC/9 (2007), see particularly paras. $1,7,11,25,32,33,37,48$, and 71 on their participatory rights specifically. 83 See the preamble, and general principle (c) of art. 3, of the International Convention on the Protection and Promotion of the Rights and Dignity of Persons with Disabilities, G.A. Res. 61/106, Annex I, U.N. GAOR, 61st Sess., Supp. No. 49, at 65, U.N. Doc. A/61/49 (2006), entered into force 3 May 2008. See also the work in this area by the Committee on Economic, Social and Cultural Rights, particularly: General Comment No. 5: Persons with disabilities (Eleventh session, 1994), U.N. Doc E/1995/22 at 19 (1995), reprinted in Compilation of General Comments and General Recommendations Adopted by Human Rights Treaty Bodies, U.N. Doc. HRI/GEN/1/Rev.6 at 24 (2003). Note that the EU recently has codified a right of persons with disabilities to participate in the life of the community: art. 26 of the Charter of Fundamental Rights of the European Union, 2000/C 364/01, which has legally binding force as per the Lisbon Treaty.

${ }_{84}$ Article 29(b).

85 Article 29(b)(i)

86 Article 30

87 Article 9.

88 Article 19.

89 Article 24.

90 Articles 33(3) and 34(4).

91 See Article 41 of the International Convention on the Protection of the Rights of All Migrant Workers and Members of Their Families, G.A. res. 45/158, annex, 45 U.N. GAOR Supp. (No. 49A) at 262, U.N. Doc. A/45/49 (1990), entered into force 1 July 2003.

${ }_{92}$ Article 42(2). Other participatory rights can be found in Article 43(g)(participation in cultural life) and 51 (participation in public work schemes).
} 
other fundamental rights; that is, the legal exercise of reading the right to (public) participation in conjunction with other substantive human rights enshrined in the respective convention. However, not every instance discussed so far would appear to have been inspired by the need to tackle the challenges posed by privatisation. More often than not, the need for extending the scope of participatory rights to specific areas covered by substantive human rights is considered as a necessary end in itself (e.g. children's participation in national human rights institutions; participation of migrant workers in decisions concerning the life and administration of local communities; or participation by persons with disabilities in the monitoring process of rights of persons with disabilities).

The Committee on the Elimination of Discrimination against Women has more or less acknowledged the issue of privatisation, ${ }^{93}$ but has barely elaborated upon the pertinent questions posed by this process. The Human Rights Committee has hardly acknowledged the impact of privatisation on the right to public participation (save in the interrelated area of access to information). ${ }^{94}$ Moreover, from the Views issued by the Human Rights Committee one could deduce the notion that there is no such thing as a concrete right to direct participation by stakeholders (possibly even in the event privatisation affects legitimate interests). It may be argued that a more satisfactory reading of the use of the word 'or' in paragraph (a) of Article 25 of the ICCPR would require that the state take into account all relevant specific (political as well as macroeconomic; national as well as local) circumstances, including processes of privatisation. This approach could mean that the occasional specific circumstances warrant fulfilment of a concrete right to be involved in decision-making processes, namely when decisions could affect the rights or legal position of identifiable stakeholders.

In this respect, the Human Rights Committee's approach would benefit from the approach taken by the Committee on the Elimination of Racial Discrimination concerning similar questions. The Committee on the Elimination of Racial Discrimination has predominantly - and given the nature of its mandate perhaps not surprisingly so - engaged with the problems posed by nationalisation or expropriation (rather than privatisation), particularly in the area of land and property rights of indigenous peoples. Be that as it may, this Committee has repeatedly argued that effective participation in public life also means that no decisions directly relating to their rights and interests may be taken without the informed consent of stakeholders - a notion that may also prove very valuable and pertinent regarding the issue of privatisation.

It has been argued that privatisation might affect the enjoyment of fundamental rights: thus far the focus has been on the right to public participation, its general as well as its more specific versions, how far these rights stretch, and to what extent different monitoring bodies have responded - or failed to respond - to the challenge of privatisation. The next step is to come to terms with the fact that also other fundamental rights may be affected by processes of privatisation. Presently, it is solely the Committee on Economic, Social and Cultural Rights that truly deals practically with the issue of privatisation in its work. Also, it is certainly no coincidence that the Committee on Economic, Social and Cultural Rights has, in recent times, started mainstreaming participatory rights with the substantive human rights it monitors, especially in those areas where the individual is dependent on a private provider to pick the fruits of one's individual (socio-economic) entitlements.

\section{Mainstreaming Participatory Rights with Socio-Economic Rights as an Answer to Privatisation}

The fact that the Committee on Economic, Social and Cultural Rights acknowledges, chiefly in its general comments, the need to thoroughly mainstream the right to public participation with substantive socio-economic rights is all the more interesting in light

\footnotetext{
3 See text referenced by and within above n. 56 .

94 See Gauthier v. Canada, above n. 32, and the surrounding text.
} 
of the fact that the ICESCR does not, in actual fact, contain a generic (political) right to public participation. ${ }^{95}$ Thus, this ongoing mainstreaming exercise is the representation par excellence of the doctrine of the indivisibility of human rights.

These mainstreaming exercises are most apparent in the areas of (entitlements to): adequate housing; adequate food and water; employment; social security; health; socioeconomic rights of persons with a disability; rights to benefit from the protection of the moral and material interests resulting from any scientific, literary or artistic production; and the more generic issue of the equal right of men and women to the enjoyment of all economic, social and cultural rights.

In the area of housing, the Committee on Economic, Social and Cultural Rights first of all points out that processes of privatisation do not discharge the state's obligations to ensure adequate housing:

Measures designed to satisfy a State party's obligations in respect of the right to adequate housing may reflect whatever mix of public and private sector measures considered appropriate. While in some States public financing of housing might most usefully be spent on direct construction of new housing, in most cases, experience has shown the inability of Governments to fully satisfy housing deficits with publicly built housing. The promotion by States parties of "enabling strategies", combined with a full commitment to obligations under the right to adequate housing, should thus be encouraged. In essence, the obligation is to demonstrate that, in aggregate, the measures being taken are sufficient to realize the right for every individual in the shortest possible time in accordance with the maximum of available resources. ${ }^{96}$

Furthermore, domestic legal remedies must be in place so as to address complaints against illegal actions carried out or supported by landlords (e.g. in relation to rent levels), whether public or private. ${ }^{97}$ Turning to the importance of public participation, the Committee on Economic, Social and Cultural Rights has considered that, presently, the right to adequate housing (included in article 11 of the ICESCR) could become meaningless if this right continues to be viewed in isolation from other fundamental rights, notably 'the right to participate in public decision-making, ${ }^{98}$ The Committee argues that a state's national housing strategy:

should reflect extensive genuine consultation with, and participation by, all of those affected, including the homeless, the inadequately housed and their representatives. Furthermore, steps should be taken to ensure coordination between ministries and regional and local authorities in order to reconcile related policies (economics, agriculture, environment, energy, etc.) with the obligations [in the area of adequate housing]. ${ }^{99}$

Special legislation protecting people from forced evictions must not only apply in relation to all agents acting under the authority of the state or who are accountable to it. The Committee argues that states 'in view of the increasing trend in some States towards their government greatly reducing their responsibilities in the housing sector', must ensure that legislative measures are in place to prevent or punish illegitimate forced evictions carried out by private actors..$^{100}$

\footnotetext{
95 The ICESCR does contain a specific right to take part in cultural life. See also: text referenced by and within above n. 61.

96 General Comment 4: The right to adequate housing (Sixth session, 1991), U.N. Doc. E/1992/23, annex III at 114 (1991), reprinted in Compilation of General Comments and General Recommendations Adopted by Human Rights Treaty Bodies, U.N. Doc. HRI/GEN/1/Rev.6 at 18 (2003), para. 14.

97 Id., para 17. See also: para. 8 on private accommodation.

98 Id., para. 9, also explicitly referring to the need to read in conjunction the two Covenants (i.e. the ICESCR and the ICCPR) on these issues.

99 Id., para. 12.

100 General Comment 7: Forced evictions, and the right to adequate housing (Sixteenth session, 1997), U.N. Doc. E/1998/22, annex IV at 113 (1997), reprinted in Compilation of General Comments and General
} 
Concerning the food sector, the Committee has similarly acknowledged the potentially negatively effect that the ongoing processes of privatisation may have on the enjoyment of the right to adequate food. The Committee has stated that states parties to the ICESCR should 'take appropriate steps to ensure that activities of the private business sector and civil society are in conformity with the right to food' as part of their obligations to protect people's food resource base. ${ }^{101}$ Among other things, the Committee infers from this general obligation the specific duty requiring a national strategy on access to adequate food to be put in place, paying particular attention to necessary collaboration with the private sector (as well as civil society and international organizations). ${ }^{102}$ Again, we see how the Committee tries to nip in the bud challenges posed by privatisation by mainstreaming access to food policies with participatory rights of stakeholders (who are in this case, everyone). The Committee holds that the actual formulation and implementation of national strategies for the right to food requires full compliance with the principle of 'people's participation' ${ }^{103}$ It is interesting to note that in the area of equal access to adequate food, the Committee goes one step further still. Short of considering the private food sector direct duty bearers under international law, the Committee urges private providers to assume responsibility in the area of access to adequate food:

While only States are parties to the Covenant and are thus ultimately accountable for compliance with it, all members of society - individuals, families, local communities, non-governmental organizations, civil society organizations, as well as the private business sector - have responsibilities in the realization of the right to adequate food. The State should provide an environment that facilitates implementation of these responsibilities. The private business sector - national and transnational - should pursue its activities within the framework of a code of conduct conducive to respect of the right to adequate food, agreed upon jointly with the Government and civil society. ${ }^{104}$

Elsewhere, the Committee further reiterates this, emphasising that a right to adequate food includes access to food free from adverse substances, which can only be realised if both public and private providers take protective measures. ${ }^{105}$

In the area of access to water, the challenges faced by privatisation are equally acknowledged, as is the necessary focus on the right to participation in essential decision-making processes, as the key to mediating the adverse effects in this area. States parties must adopt the necessary measures to ensure that water distribution services are affordable for all. ${ }^{106}$ The Committee further considers that: 'In order to create a favourable climate for the realization of the right, States parties should take appropriate steps to ensure that the private business sector and civil society are aware of, and consider the importance of, the right to water in pursuing their activities'. ${ }^{107}$ Again, this means that the state's national strategy on access to water should pay special attention to necessary collaboration with the private sector. The key to successfully tackling the issue lies in public participation:

Where water services (such as piped water networks, water tankers, access to rivers and wells) are operated or controlled by third parties, States

Recommendations Adopted by Human Rights Treaty Bodies, U.N. Doc. HRI/GEN/1/Rev.6 at 45 (2003), para. 10.

${ }_{101}$ General Comment 12: Right to adequate food (Twentieth session, 1999), U.N. Doc. E/C.12/1999/5 (1999), reprinted in Compilation of General Comments and General Recommendations Adopted by Human Rights Treaty Bodies, U.N. Doc. HRI/GEN/1/Rev.6 at 62 (2003), para. 27.

${ }^{102}$ Id., para. 27.

103 Id., para. 23.

104 Id., para. 20.

105 See, id., paras. 8 and 10.

106 General Comment 15: The right to water (Twenty-ninth session, 2003), U.N. Doc. E/C.12/2002/11 (2002), reprinted in Compilation of General Comments and General Recommendations Adopted by Human Rights Treaty Bodies, U.N. Doc. HRI/GEN/1/Rev.6 at 105 (2003), para. 27.

107 Id., para. 49. 
parties must prevent them from compromising equal, affordable, and physical access to sufficient, safe and acceptable water. To prevent such abuses an effective regulatory system must be established... which includes independent monitoring, genuine public participation and imposition of penalties for non-compliance. ${ }^{108}$

Therefore, participation in decision-making processes that affect individuals' exercise of the right to water must be an integral part of any policy concerning water. ${ }^{109}$ Devising and periodically reviewing a national water strategy and plan of action addressing the whole population on the basis of a participatory and transparent process is, in actual fact, mentioned by the Committee as one of the so-called core obligations in relation to the right to water. ${ }^{110}$

In the area of employment, the Committee has also acknowledged the challenges posed by privatisation. Sticking to Maastricht Guidelines' innovative tripartite framework of state obligations (i.e. the obligations to respect, protect and fulfil), ${ }^{111}$ the Committee emphasises in the context of the obligation to protect, that protecting the right to work includes the duties of states parties to adopt legislation or to take other measures ensuring 'that privatisation measures do not undermine workers' rights' ${ }^{112}$ This means, among other things, that states parties must prohibit and combat forced or compulsory labour by non-state actors. Combating discrimination and unequal treatment of disadvantaged and marginalized individuals or groups in both the public and the private sectors is considered one of the core obligations under the right to work. ${ }^{113}$ In a section of the General Comment entitled 'Obligations of Actors other than States Parties' the Committee considered that:

all members of society - individuals, local communities, trade unions, civil society and private sector organizations - have responsibilities regarding the realization of the right to work. States parties should provide an environment facilitating the discharge of these obligations. Private enterprises - national and multinational - while not bound by the Covenant, have a particular role to play in job creation, hiring policies and non-discriminatory access to work. They should conduct their activities on the basis of legislation, administrative measures, codes of conduct and other appropriate measures promoting respect for the right to work, agreed between the government and civil society. ${ }^{114}$

The key to promoting equal access to employment lies again in the formulation and implementation of an adequate national strategy that mainstreams participatory rights. An adequate national strategy on employment should also include 'effective involvement of the community and, more specifically, of associations for the protection and promotion of the rights of workers and trade unions in the definition of priorities, decision-making, planning, implementation and evaluation of the strategy to promote employment'. ${ }^{115}$ Mainstreaming participatory rights in combination with general efforts to promote employment is considered another core obligation under the right to work. ${ }^{116}$

\footnotetext{
108 Id., para. 24. In this regard, the Committee has, for instance, expressed concern about access to and distribution of water to all people living in the occupied Palestinian territories, and urged Israel to ensure that 'all parties concerned participate fully and equally in the process of water management, extraction and distribution' (E/2004/22 (2003) 42 [Israel]).

109 Id., para. 48.

110 Id., para. 37.

111 Maastricht Guidelines on Violations of Economic, Social and Cultural Rights, Maastricht, 22-26 January 1997; which doctrinal framework is frequently drawn on in the Committee's post-1997 General Comments.

112 General Comment 18: The right to work (Thirty-fifth session, 2006), U.N. Doc. E/C.12/GC/18 (2006), para. 25 .

113 Id., para. 31(b). This is further strengthened by considerations on the role the state must play vis-à-vis the private sector in paras. 26,38 and 43 .

114 Id., para. 52.

115 Id., para 42.

116 Id., para 31(c).
} 
Turning to the issue of social security, the Committee first of all posits that in addition to public schemes, privately run schemes, forms of self-help and other measures such as community-based or mutual schemes, are in principle compatible with the ICESCR, as long as such schemes conform to the essential elements of, and can be viewed as contributing to the right to social security. ${ }^{117}$ That said, the Committee points out that '[w] here social security schemes, whether contributory or non-contributory, are operated or controlled by third parties, States parties retain the responsibility of administering the national social security system and ensuring that private actors do not compromise equal, adequate, affordable, and accessible social security'. ${ }^{118}$ The same arguments extend more specifically to private pension schemes, private social insurance schemes, and private health insurance schemes (see also infra). ${ }^{119}$ To prevent abuses, an effective regulatory system must be established which includes genuine public participation: 'Beneficiaries of social security schemes must be able to participate in the administration of the social security system. The system should be established under national law and ensure the right of individuals and organizations to seek, receive and impart information on all social security entitlements in a clear and transparent manner'. ${ }^{20}$

The Committee has acknowledges the challenges posed by privatisation in the area of health (care):

Obligations to protect include, inter alia, the duties of States to adopt legislation or to take other measures ensuring equal access to health care and health-related services provided by third parties; to ensure that privatization of the health sector does not constitute a threat to the availability, accessibility, acceptability and quality of health facilities, goods and services; to control the marketing of medical equipment and medicines by third parties; and to ensure that medical practitioners and other health professionals meet appropriate standards of education, skill and ethical codes of conduct. ${ }^{121}$

In the area of health, too, the Committee emphasises that, despite the fact that it is ultimately only the state that can be held accountable for failing to discharge its international duties, it is not only the state that bears responsibility: non-state actors, including health professionals, families, local communities, intergovernmental and nongovernmental organizations, civil society organizations, as well as the private business sector, all have responsibilities in helping to realise the right to health. ${ }^{122}$ The Committee refers to the participation of the population in the provision of preventive and curative health services as one of the core obligations under the right to health. ${ }^{123}$ Participatory rights must pertain to 'the organization of the health sector, the insurance system and, in particular, participation in political decisions relating to the right to health taken at both the community and national levels'. ${ }^{124}$ Participatory rights in the area of health and wellbeing also have a special focus on the rights of older persons: they must be in a position to participate actively in the formulation and implementation of policies that affect their well-being particularly. ${ }^{125}$

\footnotetext{
117 General Comment 19: The right to social security (art. 9) (Thirty-ninth session, 2007), U.N. Doc. E/C.12/GC/19 (2008), para. 5.

118 Id., para. 46. See also para. 17

119 Id., paras. 9, 13, 32, and 34.

120 Id., para. 26, as further emphasised in paras. 42, 46, 69,

121 General Comment 14: The right to the highest attainable standard of health (Twenty-second session, 2000), U.N. Doc. E/C.12/2000/4 (2000), reprinted in Compilation of General Comments and General Recommendations Adopted by Human Rights Treaty Bodies, U.N. Doc. HRI/GEN/1/Rev.6 at 85 (2003), para. 35 (emphasis in original).

122 Id., para. 42, further underscored in paras. 55 and 56

123 Id., para. 43(f). Further underscored in paras. 11, 23, 34, and 54.

124 Id., para. 17.

125 General comment No. 6: The economic, social and cultural rights of older persons (Thirteenth session, 1995), U.N. Doc. E/1996/22 at 20 (1996), reprinted in Compilation of General Comments and General Recommendations Adopted by Human Rights Treaty Bodies, U.N. Doc. HRI/GEN/1/Rev.6 at 34 (2003), paras. 5 and 39. Note that the EU recently has codified a right of the elderly to participation: Article 25 of
} 
In the area of access of persons with a disability, the UN Secretary-General had already indicated as early as 1992 that ongoing developments, including privatisation, have especially negatively impacted upon the access and participation of persons with disabilities:

Current economic and social deterioration, marked by low-growth rates, high unemployment, reduced public expenditure, current structural adjustment programmes and privatisation, have negatively affected programmes and services...If the present negative trends continue, there is the risk that [persons with disabilities] may increasingly be relegated to the margins of society, dependent on ad hoc support. ${ }^{126}$

Building on these concerns, the Committee on Economic, Social and Cultural Rights considers:

Given the increasing commitment of Governments around the world to market-based policies, it is appropriate in that context to emphasize certain aspects of States parties' obligations. One is the need to ensure that not only the public sphere, but also the private sphere, are, within appropriate limits, subject to regulation to ensure the equitable treatment of persons with disabilities. In a context in which arrangements for the provision of public services are increasingly being privatized and in which the free market is being relied on to an ever greater extent, it is essential that private employers, private suppliers of goods and services, and other non-public entities be subject to both non-discrimination and equality norms in relation to persons with disabilities. In circumstances where such protection does not extend beyond the public domain, the ability of persons with disabilities to participate in the mainstream of community activities and to realize their full potential as active members of society will be severely and often arbitrarily constrained. ${ }^{127}$

Concerning a different area altogether, privatisation may furthermore affect the public's right to benefit from the protection of the moral and material interests resulting from any scientific, literary or artistic production of which he or she is the author (article 15 , paragraph 1 (c), of the ICESCR), in so far the process of privatisation results in a situation where it is no longer only the state that influences the protection of these moral and material interests. Therefore, the Committee has provided that states parties must create a favourable climate for the realisation of that right. This means that states must take appropriate steps to ensure that the private business sector is not only aware of but also pro-actively considers the effects on the enjoyment of other human rights upon the right to benefit from the protection of the moral and material interests resulting from one's scientific, literary and artistic productions. ${ }^{128}$ States that have ratified the ICESCR are further urged to consider regulating the responsibility resting on the private business sector, private research institutions and other non-state actors to respect the relevant rights. ${ }^{129}$ Failure to ensure the informed participation of authors and groups of authors in any decision-making process that has an impact on their right to benefit from the protection of the moral and material interests resulting from their productions may constitute a violation of the duty to fulfil the right at stake. ${ }^{130}$

the Charter of Fundamental Rights of the European Union, 2000/C 364/01, which entered into force as per the Lisbon Treaty.

126 A/47/415, para. 5 (as referenced by the Committee on Economic, Social and Cultural Rights its General Comment No. 5).

127 General Comment No. 5: Persons with disabilities (Eleventh session, 1994), U.N. Doc E/1995/22 at 19 (1995), reprinted in Compilation of General Comments and General Recommendations Adopted by Human Rights Treaty Bodies, U.N. Doc. HRI/GEN/1/Rev.6 at 24 (2003), para. 11.

128 General Comment 17: the right of everyone to benefit from the protection of the moral and material interests resulting from any scientific, literary or artistic production of which he or she is the author, U.N. Doc. E/C.12/GC/17 (2006), para. 48.

129 Id., para. 55.

130 Id., para. 34. 
In the context of ensuring the generic equal right of men and women to the enjoyment of all economic, social and cultural rights, the Committee once more directly dealt with the issue of privatisation. The Committee emphasises in the context of the obligation to protect that in cases where public services have been partially or fully privatised, states parties have an obligation 'to monitor and regulate the conduct of non-state actors to ensure that they do not violate the equal right of men and women to enjoy economic, social and cultural rights'. ${ }^{131}$ It is furthermore an important aspect of the state's obligation to fulfil to pro-actively guarantee equal participation of men and women in decisionmaking in all programmes related to the realisation of economic, social and cultural rights. ${ }^{132}$

\section{Education: The Limits of Participatory Rights in Times of Privatisation}

Participatory rights are not, however, the remedy to the issues of privatisation in each and every substantive area that was once considered a "public affair". A prime example of this would be the case of education. ${ }^{133}$ Particularly in the event that education is 'contracted out', as it were, to (private) religious institutions, it is difficult to see how a complimentary focus on participatory rights could remedy a lack of access. Nonreligious parents, or parents adhering to a different religion, would likely be unwilling to participate in the affairs of schools that affiliate with a religion that is not theirs; after all, this would probably be the reason why they would not send their children to the school in question. Moreover and importantly, it cannot reasonably be expected that they rely on the available participatory rights to try to mend interferences with their parental liberties and their children's rights.

This concern is far from academic, as indicated by the workings of the treatymonitoring bodies. ${ }^{134}$ First of all, it should be made clear that international human rights law does not take a stance against private (or specifically religious) schools per se. ${ }^{135}$ The state must respect the right of parents not to avail of the schools established by the public authorities and their choice to opt for private educational institutions (for instance, so as to ensure the religious and moral education of their children in conformity with their own convictions). ${ }^{136}$ That said, the foremost positive obligation flowing from the right to education is for the state to ensure sufficient public schooling

\footnotetext{
131 General Comment 16: Article 3: the equal right of men and women to the enjoyment of all economic, social and cultural rights (Thirty- fourth session, 2005), U.N. Doc. E/C.12/2005/3 (2005), para. 20.

${ }_{132}$ Id. para. 21 (final bullet point). Other elements of participatory rights are mentioned in paras. 14, 31 and 37.

${ }_{133}$ Perhaps it is no coincidence that Committee on Economic, Social and Cultural Rights, in its General Comment on the right to education (see Committee on Economic, Social and Cultural Rights, General Comment 13: The right to education (Twenty-first session, 1999), U.N. Doc. E/C.12/1999/10 (1999), reprinted in Compilation of General Comments and General Recommendations Adopted by Human Rights Treaty Bodies, U.N. Doc. HRI/GEN/1/Rev.6 at 70, 2003), unlike virtually all the other Comments on substantive socio-economic rights (as extensively outlined in section 3 above), does not mainstream participatory rights concerning the right to education (the references to participation in paras. 1,4 , and 30 , id., do not have the effect of mainstreaming participatory rights, but rather refer to the intended output of adequate education: participation in a free society; while the references to participation in paras. 39-40 are reserved for participatory rights in higher and academic education, as stated in para. 38, id.). That is, despite the fact that the Committee does recognise the challenge also posed by privatisation in relation to access to education (e.g., Id., at para. 41, on the need to ensure that school discipline is in accordance with the ICESCR in private schools; and para. 59, Id., on the need to ensure that private educational institutions conform to the minimum educational standards).

134 This section draws on J.D. Temperman, 'State Neutrality in Public School Education', 32 Human Rights Quarterly 4, at 873-875.

135 The state is under no duty, however, to fund such private educational establishments, e.g.: General Comment 13, at para. 54 .

${ }_{136}$ As long as these schools conform to such minimum educational standards laid down by the state. E.g. Articles 13, paras. (3) and (4), of ICESCR; art. 5, para. (1)(b), of the UNESCO Convention against Discrimination in Education of 14 December 1960; also implied by art. 5, para. (2) of the Declaration on the Elimination of All Forms of Intolerance and of Discrimination Based on Religion or Belief, G.A. res. 36/55, 36 U.N. GAOR Supp. (No. 51) at 171, U.N. Doc. A/36/684 (1981).
} 
with appropriate curricula. This means that a predominantly religious society cannot completely 'contract out' education to private religious institutions. Or, as the case may be, the state may not allow institutionalised religion to monopolise - and thus privatise - the provision of education altogether, as this would inevitably lead to concrete access issues for (religious or non-religious) minorities. The Human Rights Committee recently reproached Ireland on this issue, observing that:

the vast majority of Ireland's primary schools are privately run denominational schools that have adopted a religious integrated curriculum thus depriving many parents and children who so wish to have access to secular primary education... The State party should increase its efforts to ensure that non-denominational primary education is widely available in all regions of the State party, in view of the increasingly diverse and multiethnic composition of the population of the State party. ${ }^{137}$

If the state fails in its positive obligation to provide non-denominational education, by for instance - as would in practice often be the case - maintaining historical church prerogatives in this area, then various educational and religious rights are inevitably infringed. ${ }^{138}$ Ireland's Equality Act makes the situation for children of non-religious parents even worse as it allows denominational schools, which are virtually all Catholic, to refuse admission to pupils who do not adhere to the denomination in question. This rule is based on the arbitrary grounds of preserving the religious 'ethos of the school'. ${ }^{139}$ Such a system fosters serious human rights violations for various reasons. First, given the lack of secular state-run schools and the possibility that children of non-religious parents are turned away by denominational schools, no appropriate form of education may be available to these children. Furthermore, secular parents who would prefer religious education over no education at all might feel compelled to obtain the necessary religious affiliation, for example, by means of conversion or baptising their children to meet enrolment requirements..$^{140}$

Some treaty monitoring bodies have criticised the laissez-faire attitude on the part of the state towards education for other, perhaps even more fundamental reasons. Whenever the state fails in its positive duty to provide sufficient non-denominational state schools, the state may be actively - albeit perhaps inadvertently - contributing to religious segregation. The Committee on Economic, Social, and Cultural Rights, for instance, assessing the educational system in Northern Ireland, observed that public schools in the region are:

heavily segregated, with most Protestants attending Protestant schools and most Catholics attending Catholic schools and only approximately 2 per cent of the school population attending integrated schools. The...current government policy, which appears to consist of a willingness to consider the conversion of existing Protestant or Catholic schools into integrated schools if it is the wish of the majority in a given school, is ineffective and likely to preserve the status quo. ${ }^{141}$

Thus, generally speaking, a far more pro-active policy on making available public education is needed, especially in pluralist societies (which is, nowadays, virtually every society). Privatisation in extremis of education does not solely affect access of pupils, but also impacts on equal opportunities for the providers of education, school teachers (and, consequently, the right to work and recognized equal opportunities in

$137 \mathrm{CCPR} / \mathrm{C} / \mathrm{IRL} / \mathrm{CO} / 3$ (2008), para. 2 [Ireland].

138 See A. Mawhinney, Submission to the Human Rights Committee with Respect to the Third Periodic Report of Ireland [NGO Information], March 2008; this shadow report is a response to U.N. GAOR, Hum. Rts. Comm., U.N. Doc. CCPR/C/IRL/3, paras. 409-11

${ }_{139}$ Art. 7, para. (3)(c) of the [Irish] Equal Status Act, No. 8/2000.

140 Both problems are reported in the mentioned shadow report, above n.138, at 2, 4; similar concerns have been raised by the Committee on the Elimination of Racial Discrimination in its Conclusion Observations: A/60/18 (2005), para. 142 [Ireland].

${ }_{141} \mathrm{E} / 1998 / 22$ (1997) 56 at para. 301 (UK); reiterated in 2002: E/2003/22 (2002) 39 at paras. 226 and 245 (UK). 
that area). Religious affiliation - or the lack thereof - may, naturally, not be imposed as an occupational requirement for public school teachers or staff. However, equal opportunities in this area (employment of school teachers) run the risk of being frustrated if the state allows a situation to emerge where there are no (or insufficient) public schools available, having contracted out education altogether to private (religious) institutions, or sanctioning a situation wherein religious institutions monopolise the running of education, including the appointment of school teachers. ${ }^{142}$

Though private religious education is certainly a unique form of privatisation, it provides an illustration of precisely the type of contentious area in which participatory entitlements may be limited in their function as remedial rights.

\section{Conclusion}

In the light of the challenges posed by privatisation, the time seems right to rethink the discourse on public participation. Human rights conventions are considered living instruments, capable of re-adjusting to contemporary challenges and issues. ${ }^{143}$ The issue of privatisation poses a definite contemporary challenge. ${ }^{144}$ Privatisation affects the enjoyment of the right to public participation itself, but also impacts on other rights. The key to remedying this situation lies largely - though not exclusively or necessarily, as illustrated in the case of the privatisation of education (see section 4) - in a critical, renewed discourse concerning participatory rights.

Starting with the right to public participation itself, we have seen (in section 2) how the right to public participation has traditionally been rather tightly linked to the exercise of governmental power: participatory rights as a right to engage, actively or passively, in politics. In the meantime, however, a number of specialised human rights conventions have broadened the scope of participatory rights considerably. The sum of these standards can be taken to construe the right to public participation, in line with contemporary developments and notably in line with privatisation, so as to create a standard that goes beyond a mere generic duty upon the state to organise regular, free elections. Treaty-monitoring bodies should take into account all relevant specific - political as well as macro-economic; national as well as local - circumstances, including processes of privatisation. This approach could mean that occasionally, specific circumstances warrant fulfilment of a concrete right to be directly involved

\footnotetext{
142 The Human Rights Committee has, for instance, condemned Costa Rican legislation (A/49/40 vol. I (1994), paras. 158 and 162) which confers on the National Episcopal Conference the power to select teachers for religious instruction, a step that effectively means that non-Catholics are barred from teaching religion subjects in the public school curricula. It stands to reason that a very limited religious occupational requirement scheme could apply to the specific position of religious instructor (in both denominational schools as well as public schools that have a religion subject on the curriculum), except if the religion subject is a neutral subject about religions rather than religious instruction. However, that does not mean that the state has no obligations in this regard or that all arrangements as to hiring appropriate persons to teach the religion subject suffice. In the case at hand, the influence exercised by Catholic Bishops' Conference was such that appointment of non-Catholics was unlikely.

${ }^{143}$ For a practical account on the living instrument doctrine or approach, see P. Plowden and K. Kerrigan, Advocacy and Human Rights: Using the Convention in Courts and Tribunals (2004), particularly at 26-27. See also M.P. Van Alstine, 'Dynamic Treaty Interpretation', 146 University of Pennsylvania Law Review 3 (1998), at 687-793. Particularly the European Court of Human Rights has consistently argued in its case law that the European Convention on Human Rights must be seen as a 'living instrument' which 'must be interpreted in the light of present-day conditions' (e.g. Soering v. the United Kingdom, ECHR, (1989), Application No. 14038/88, 102; Leyla Sahin v. Turkey, ECHR, (2005), Application No. 44774/98, 136; Loizidou v. Turkey (Preliminary Objections), ECHR, (1995), Application No. 15318/89, 71). For an analysis of the dynamic treaty interpretation doctrine at the Council of European level, see, e.g., R. Bernhardt, 'Evolutive Treaty Interpretation, Especially of the European Convention on Human Rights', 42 German Yearbook of International Law 11 (1999), at 11-25. The Human Rights Committee, too, has considered 'that the [ICCPR] should be interpreted as a living instrument and the rights protected under it should be applied in context and in the light of present-day conditions' (e.g. Roger Judge v. Canada, Communication No. 829/1998, U.N. Doc. CCPR/C/78/D/829/ 1998 (2003), Views of 5 August 2002).

${ }_{144}$ As does the issue of globalization, for that matter-something that goes beyond the scope of the present account (see, however, the text referenced by and within above n. 30).
} 
in decision-making processes, namely when decisions could affect the rights or legal position of identifiable stakeholders. In sum, effective participation in public life in times of privatisation must be construed so as to mean that no decisions directly affecting stakeholders' rights and interests may be taken without their informed participation, if not informed consent.

Privatisation, in addition to impacting the right to public participation itself, risks negatively affecting other substantive rights, for example individual entitlements to adequate housing, adequate food and water, work, social security or health (see section 3 ). The key to remedying the negative effects resulting from privatisation again lies largely in a renewed discourse on participatory rights. In the present context, efforts to mainstream participatory rights with the different substantive areas, as carried out by the Committee on Economic, Social and Cultural Rights, significantly mitigate the ramifications of privatisation. As long as states ensure the informed consent, and at least the informed participation, of groups or individuals in both public and private decisionmaking processes that potentially impact upon their legal position and on their rights and the enjoyment thereof, most fundamental rights can be fulfilled despite privatisation processes.

The example of privatisation of education, however, shows that one must be realistic about the potential and the limitations of participatory rights in relation to the challenge posed by privatisation (see section 4). Discourse on effective participation in public life in times of privatisation, emphasising that decisions directly affecting rights and interests should not be taken without the informed participation, if not informed consent, of stakeholders, will be increasingly important. The complimentary focus on mainstreaming participatory rights with all relevant substantive human rights in areas where the individual is dependent on a private provider for his or her enjoyment of individual (socio-economic) entitlements will also become more imperative. Participatory rights, however, are not a wholesale solution to the challenge that is privatisation. In areas where a renewed discourse on participatory rights cannot provide a remedy for privatisation, the only alternative lies in reiterating the state's positive state obligations, and more specifically, emphasising the fact that the state remains at all times the ultimate duty bearer under international law and is primarily responsible for ensuring that human rights obligations are fulfilled. This may mean that the state will not be allowed to stand by idle when certain public policy matters become fully privatised. 